\title{
RECORD OF A LIVE OCELOT (LEOPARDUS PARDALIS) AT LA MICHILÍA BIOSPHERE RESERVE, DURANGO, MEXICO
}

\author{
Jorge Servín ${ }^{1,4}$, Luis E. Aguilar-Jiménez ${ }^{1,2}$, Edgar F. Hernández-Reyes ${ }^{1,2}$, \\ Joaquín Tinoco ${ }^{1,2}$, and Jesús Sanchez-Robles ${ }^{3}$
}

\begin{abstract}
The first confirmed record of a live ocelot (Leopardus pardalis) in the state of Durango, and in La Michilía Biosphere Reserve, is reported here. This record is based on a photograph of an adult taken during a 2015 winter phototrapping survey. This noteworthy record extends the ocelot's geographic distribution by $>120 \mathrm{~km}$ from the nearest record in Sinaloa, Mexico. The record locality is also in oak forest at an unusually high altitude of $2750 \mathrm{~m}$ asl for an ocelot in Mexico.

RESUMEN.-Se informa del primer registro confirmado de Ocelote vivo (Leopardus pardalis) en el estado de Durango y también para la Reserva de la Biosfera La Michilía, Durango, México. El registro se basa en una fotografía de un individuo adulto, obtenida en el monitoreo invernal de la comunidad de grandes vertebrados por medio de foto-trampeo. Este notable registro extiende el área de distribución de este félido por más de $120 \mathrm{~km}$ a partir del registro más cercano en el estado de Sinaloa. Es un registro con una inusual altitud de $2750 \mathrm{msnm}$ y en un bosque de Encino (Quercus spp.).
\end{abstract}

The ocelot (Leopardus pardalis) is a mediumsized mammal in the order Carnivora and family Felidae. It has a total length of 920-1367 $\mathrm{mm}$ and mass of 6-15 kg (Hall 1981, Murray and Gardner 1997, Aranda 2005). The ocelot has a wide geographic distribution, ranging from the southern United States of America to northern Argentina (Hall 1981, Murray and Gardner 1997). In Mexico, it is distributed along both coastal plains. These disjunct portions of the distribution converge in the southern center of the country, primarily within the regions of the Neovolcanic belt, the Tehuantepec Isthmus in Chiapas, and the Yucatan Peninsula (Hall 1981, Aranda 2005). There were no records in the Mexican Central Plateau, nor in the states of Zacatecas, Durango, and Coahuila. Historically, the ocelot has been found within habitats such as tropical evergreen forest, semideciduous and deciduous tropical forests, mountain cloud forest, mangrove forest, and less frequently in xerophytic scrubland (Murray and Gardner 1997, Aranda 2005). In recent years it has been recorded in sites not previously reported in Mexico, increasing the known distribution range for this felid (Iglesias et al. 2008, Bárcenas and Medellín 2010, Ramírez-Bravo 2010 et al.,
Ahumada-Carrillo et al. 2013, Valdez-Jiménez et al. 2013, Aranda et al. 2014). The ocelot is an endangered species in Mexico (SEMARNAT 2010) and has been listed in Appendix I of CITES since 1990 (http://www.cites.org/esp/ app/index.php).

The record for this live ocelot was obtained during monitoring of the community for larger vertebrates in La Michilía Biosphere Reserve (MBR), Durango, Mexico (Fig. 1). Thirty camera-trap stations were distributed in a $90-\mathrm{km}^{2}$ area. Each station was equipped with a Cuddeback ${ }^{\circledR}$ trail-camera (model Long Range IR E2) and baited with an open 350-g can of sardines in tomato sauce (CALMEX ${ }^{\circledR}$ ). The trail-cameras were active 24 hours per day and programmed with a one-minute delay after each photo. The camera-traps were active for 55 continuous days (3 Feb-29 Mar 2015) for a total sampling effort of 1650 trap-days. The camera-trap station that "captured" the ocelot was located at $23^{\circ} 26.028^{\prime} \mathrm{N}, 104^{\circ} 16.681^{\prime} \mathrm{W}$. The record obtained on 10 February 2015 in the early morning (03:44) showed an adult ocelot (Fig. 2) walking in a dense understory of manzanita (Arctostaphylos pungens). The surrounding habitat consisted of an oak (Quercus alba) forest containing some madrone (Arbutus

\footnotetext{
${ }^{1}$ Laboratorio de Ecología y Conservación de Fauna Silvestre, Departamento El Hombre y su Ambiente, Universidad Autónoma Metropolitana Unidad Xochimilco, Calz. Del Hueso No. 1100, Ciudad de México, 04960, México.

${ }^{2}$ VISILMEX, A.C., Calz. De la Virgen \#3000 Edif. 34-15, Col. Carmen Serdán, C.P. 04910, México, D.F.

${ }^{3}$ Laboratorio de Estadística, Departamento El Hombre y su Ambiente, Universidad Autónoma Metropolitana Unidad Xochimilco. Calz. Del Hueso No. 1100, 04960, México.

${ }^{4}$ E-mail: jservin@correo.xoc.uam.mx
} 


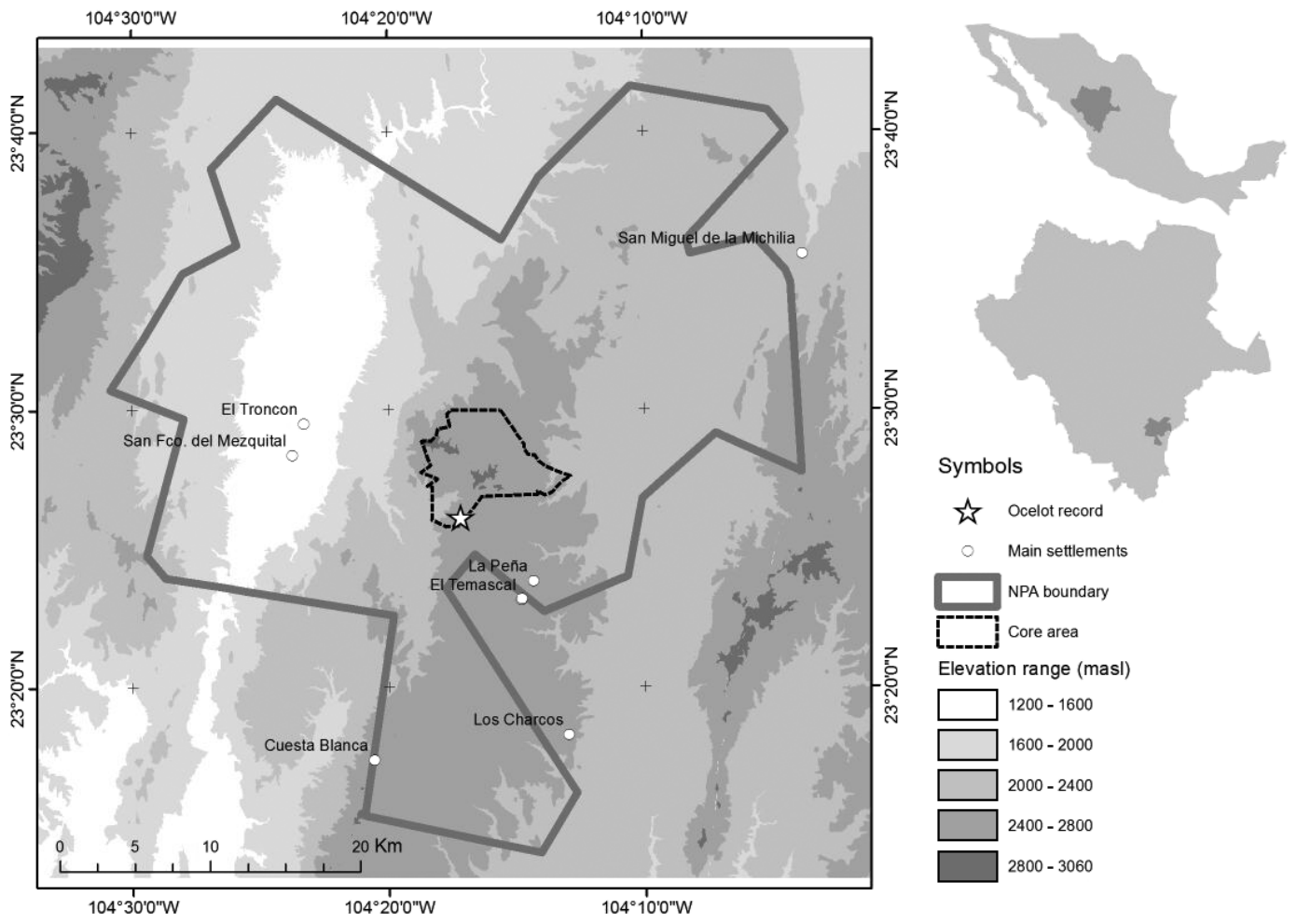

Fig. 1. The state of Durango and La Michilía Biosphere Reserve, including the location where an ocelot (Leopardus pardalis) was photographed.

xalapensis) (González-Elizondo et al. 1993), located on the mountain ridge known as "El Cordón de las Culebras," <200 m from a permanent creek known as "Arroyo El Taray." This region has been surveyed for mammals previously, and has a wide variety of small and medium-sized prey (Servin and Huxley 1991). At the same camera-trap station where the ocelot was photographed, other species "captured" included desert cottontail (Sylvilagus audubonii), black-tailed jackrabbit (Lepus californicus), white-tailed deer (Odocoileus virginianus couesi), gray fox (Urocyon cinereoargenteus), coyote (Canis latrans), and bobcat (Lynx rufus).

This record is noteworthy because it is the first confirmed record for a live ocelot both in the state of Durango and in the MBR. Further, the ocelot's occurrence at an altitude of $2750 \mathrm{~m}$ asl is uncommon (Iglesias et al. 2008, Bárcenas and Medellín 2010, AhumadaCarrillo et al. 2013, Aranda et al. 2014). The ocelot has been recorded at $3000 \mathrm{~m}$ asl, but most records in Mexico are below $1000 \mathrm{~m}$
(Aranda 2005). The ocelot was observed in an oak $(Q$. alba) forest, and only 2 other ocelot records in temperate forests have been published (Bárcenas and Medellín 2010, LópezGonzález et al. 2014). The nearest record of an ocelot in the area is $120 \mathrm{~km}$ away in the state of Sinaloa (Hall 1981). In the state of Durango, Servín et al. (2003) documented the presence of an ocelot by means of a fur sample in the possession of a villager in the San Dimas Municipality. The villager collected the ocelot fur in a tropical deciduous forest on the "Arroyo El Platanal" at $900 \mathrm{~m}$ asl $\left(24^{\circ} 0530^{\prime} \mathrm{N}, 105^{\circ} 5400^{\prime} \mathrm{W}\right)$. However, this record has not been considered in subsequent studies of ocelot geographical distribution.

Since 2010, the occurrence of ocelot records at higher sites in oak forests suggests that (a) these felines are moving to higher altitudes as a response to climate changes occurring in the places where they usually occur or (b) in recent years more-extensive survey efforts have been facilitated by new technologies (e.g., camera traps) that are optimal for detecting this kind 


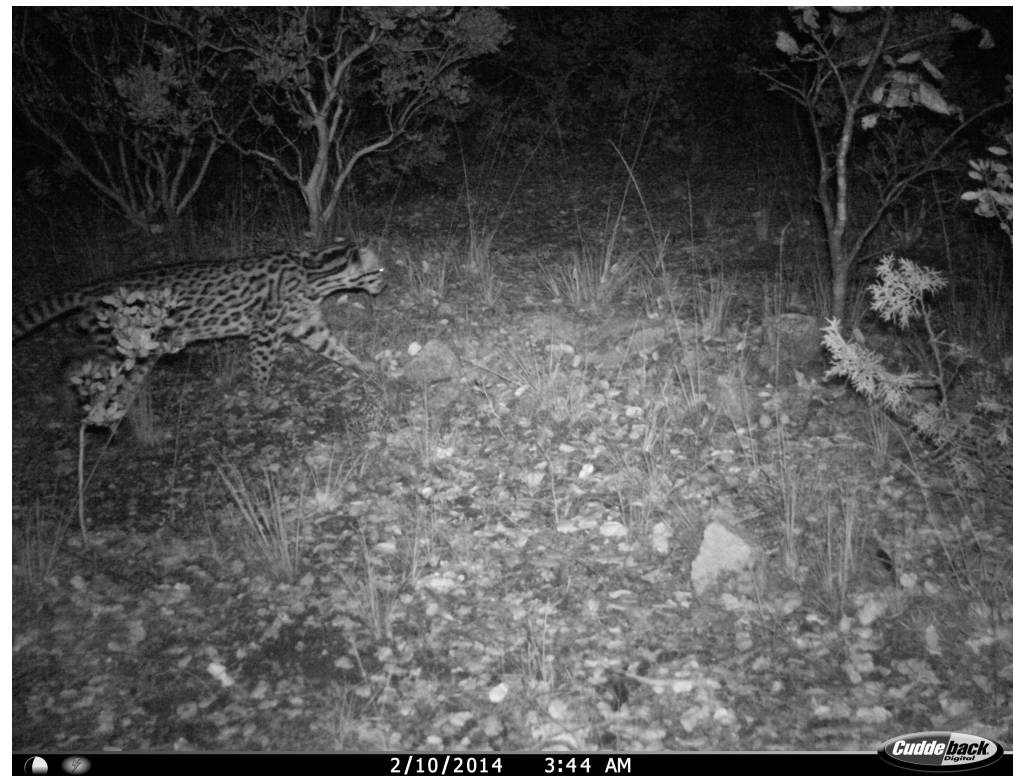

Fig. 2. Live adult ocelot (Leopardus pardalis) recorded in La Michilía Biosphere Reserve, Durango, at $2750 \mathrm{~m}$ in manzanita scrub (Arctostaphylos pungens) understory within an oak (Quercus alba) forest.

of elusive species. Both hypotheses are the subject of future research projects in Mexico.

The ocelot was observed in the northwest region of the MBR, which is an area that is rarely visited and scarcely documented in biological inventories. The MRB northwest region vegetation is a transitional zone between the Pacific coast deciduous tropical forest and the xerophytic scrublands of the Durango central highland (González-Elizondo et al. 1993, 2007). The limits of xerophytic scrublands belong to a MBR buffer zone, about $6 \mathrm{~km}$ away from the "Mezquital" river, located on the north side of the MBR. This area includes the tropical "Mezquital" river (1410 m asl) with a hot and dry climate, a temperate region dominated by temperate subhumid forests, and the MRB core area (2900 m asl). The "Mezquital" river in this region is part of the buffer zone and the MBR core area. This river begins in the center of Durango in an area with dry vegetation. It runs south through the state's central high plains and then runs west to cross the Sierra Madre Occidental. Along its path to the Pacific coast, the river crosses through zones of temperate forest, deciduous and subtropical scrublands, deciduous tropical forests, and semideciduous tropical forests. The "Mezquital" river, which connects the
Pacific coast plains with the Central Plateau south of Durango, is a biological corridor for certain animal and plant species. It functions also as a geographic barrier for other animal and plant species (Baker and Greer 1962). Thus, the biogeographical functions of this river as a corridor and/or barrier, could explain the penetration of some Neotropical species into areas of Neartic affinity in Durango and the Mexican Central Plateau.

We thank Rodolfo Pineda, Director of La Michilía Biosphere Reserve of CONANP, for his support; Pedro Roldán Morales (CONANP), Antonio Guerra, and José Medina (INECOL) for the facilities provided; and José Carlos Sánchez-Ferrer, León González Coronado, Angeles Salinas (UAM-X), and Luis Maya (U de G) for their assistance with the fieldwork. Elias Chacon made Figure 1. This research was funded by the Rector of Universidad Autónoma Metropolitana Unidad Xochimilco through the special project "Docencia y Servicio Comunitario" and the DEHA for the project "Ecología, conservación y manejo de fauna silvestre en México." VISILMEX, A.C. provided all-terrain vehicles for the fieldwork. We thank Martha Vences and Macamen Huxley for their critical reading of this manuscript, 
suggestions for improvement, and assistance in translation. We are also grateful to 2 anonymous reviewers, who provided suggestions for how to make the manuscript more readable.

\section{Literature Cited}

Ahumada-Carrillo, I.T., J.C. Arenas-Monroy, and M.A. IÑIgUEZ. 2013. Presence of ocelot (Leopardus pardalis) in northern Jalisco, Mexico. Revista Mexicana de Biodiversidad 84:718-721.

Aranda, M. 2005. Ocelote (Leopardus pardalis). Pages 359-361 in G. Ceballos and G. Oliva, coordinators, Los mamíferos silvestres de México. Fondo de Cultura Económica, Comisión Nacional para el Conocimiento y Uso de la Biodiversidad, México.

Aranda, M., F. Botello, E. Martínez-Meyer, and A. PINEDA. 2014. Primer registro de ocelote (Leopardus pardalis) en el Parque Nacional Lagunas de Zempoala, Estado de México y Morelos, México. Revista Mexicana de Biodiversidad 85:1300-1302.

BaKer, R.H., AND J.K. Greer. 1962. Mammals of the Mexican state of Durango. Publications of the Museum, Michigan State University. Biological Series 2:29-159.

BÁrcenas, J., AND R. MEdellín. 2010. Ocelot (Leopardus pardalis) in Aguascalientes, Mexico. Southwestern Naturalist 55:447-449.

GonZÁlez-Elizondo, S., M. GonZÁlEZ-Elizondo, AND A. Contés-Ortiz. 1993. Vegetación de la Reserva de la Biosfera La Michilía, Durango, México. Acta Botánica Mexicana 22:1-104.

GonZÁlez-Elizondo, S., M. GonZÁLEZ-Elizondo, AND M.A. MÁrQueZ-Linares. 2007. Vegetación y ecorregiones de Durango. México. Editorial Plaza y Valdés, Ciudad de México.

Hall, R. 1981. The mammals of North America. 2nd edition. John Wiley \& Sons, New York, NY.
Iglesias, J., V. Sánchez-Cordero, G. Magaña-Cota, R. Bolaños, M. Aranda, R. Hernández, and F.J. BotelLo. 2008. Noteworthy records of Margay, Leopardus wiedii and ocelot, Leopardus pardalis in the state of Guanajuato, Mexico. Mammalia 78:347-349.

López-González, C.A., C. Aguilar-Miguel, F. MoraCarrillo, and Z.Y. GonZÁlez. 2014. Ocelot (Leopardus pardalis): an addition to the mammals of Chihuahua, Mexico. Western North American Naturalist 74:482-484.

Murray, L.J., And L.G. Gardner. 1997. Leopardus pardalis. Mammalian Species 548.

Ramírez-Bravo, O.E., S. Schinkel-Brault, and C. HernándeZ-Santin. 2010. Nuevo registro de Ocelote (Leopardus pardalis) para el Estado de Puebla. Therya 1(1):91-94.

[SEmarnat] Secretaria del Medio Ambiente y Recursos Naturales. 2010. Norma oficial Mexicana NOM-059-ECOL-2010. Protección ambientalEspecies nativas de México de flora y fauna silvestres-Categorías de riesgo y especificaciones para su inclusión, exclusión o cambio-Lista de especies en riesgo. Diario Oficial de la Federación. México, Distrito Federal, México.

Servín, J., E. Chacón, N. Alonso-Pérez, and C. Huxley. 2003. New records of mammals from Durango, Mexico. Southwestern Naturalist 48:136-138.

Servín, J., AND C. HuxLey. 1991. La dieta del coyote en un bosque de encino-pino de la Sierra Madre Occidental de Durango, México. Acta Zoológica. Mexicana (nueva serie) 44:1-26.

Valdéz-Jiménez, D., C.M. García-Balderas, and G.E. Quintero-Díaz. 2013. Presencia del ocelote (Leopardus pardalis) en la "Sierra del Laurel," Municipio de Calvillo, Aguascalientes, México. Acta Zoológica Mexicana (nueva serie) 29:688-692.

Received 5 July 2015

Accepted 27 September 2016 